\title{
Mourning and Intermittence between Proust and Barthes
}

\author{
JENNIFER RUSHWORTH
}

\begin{abstract}
:
This essay explores the relationship between mourning and writing by tracing the various uses and connotations of the term 'intermittence' in the writings of Marcel Proust and Roland Barthes, with particular reference to the middle volume of A la recherche du temps perdu, Sodome et Gomorrhe, and to Barthes’s posthumously published Journal de deuil. Against the backdrop of the Proustian 'Intermittences of the Heart', I demonstrate that intermittence is a useful interpretive framework for Barthes's Journal in terms of the sporadic rhythm of the author's experience of grief, and suggest that this rhythm is audible in and performed by the Journal's fragmented, discontinuous form. Finally, intermittence in its etymological meaning of 'sending between' is brought to bear on broader, fundamental questions concerning the purpose of mournful writing, including to whom it is addressed and of what it speaks.
\end{abstract}

Keywords: Proust, Barthes, mourning, intermittence, mother, grandmother 


\section{Mourning and Intermittence between Proust and Barthes}

This essay considers the relationship between mourning and intermittence in Proust's A la recherche du temps perdu and Barthes's Journal de deuil (hereafter abbreviated as the Recherche and the Journal). ${ }^{i}$ I take the concept of intermittence primarily from Proust's protagonist's belated mourning for his grandmother narrated in the fourth volume of the Recherche, Sodome et Gomorrhe, whilst also drawing on the Barthesian afterlife of this same term in Le Plaisir du texte, and finally on an etymological interrogation of the word. ${ }^{\text {ii }}$ Barthes's Journal de deuil consists of a series of fragmentary, mostly dated fiches (index cards), written in the aftermath of the death of his mother (25 October 1977). This material, formerly at the IMEC (l’Institut Mémoires de l’Édition Contemporaine) and now preserved in the Bibliothèque nationale de France, was published in 2009 by Nathalie Léger, with an English translation under the title Mourning Diary appearing shortly thereafter. Readers and more specialized Barthes critics are therefore only beginning to attempt to come to grips with this enigmatic, slippery text, which challenges both in the intimate rawness of its griefstricken content and in the unhealable brokenness of its form. ${ }^{\text {iii }}$ It is particularly the latter challenge — the form of Barthes's Journal de deuil — which I propose in this essay to consider afresh, in conjunction with a varied analysis of the concept of intermittence.

The topic of Barthes as reader of Proust has already benefited from a significant number of critical contributions. ${ }^{\text {iv }}$ Barthes was not, by his own admission, a specialist in Proust; notwithstanding, the Recherche and its author appear consistently if intermittently as touchstones and leitmotive across Barthes’s varied and wide-ranging writings. ${ }^{\mathrm{v}}$ Perhaps most 
memorably, in Le Plaisir du texte, Barthes explicitly embraces Proust as an inevitable, encyclopaedic and encircling point of reference:

I recognize that Proust's work, for myself at least, is the reference work, the general mathesis, the mandala of the entire literary cosmogony (...); this does not mean that I am in any way a Proust 'specialist': Proust is what comes to me, not what I summon up; not an 'authority', simply a circular memory. Which is what the inter-text is: the impossibility of living outside the infinite text. ${ }^{\mathrm{vi}}$

That Proust is an infinite, often involuntary or inevitable intertext for Barthes is particularly evident in the Journal, in which Barthes institutes what we might call — borrowing a term from Darian Leader — 'a dialogue of mournings' vii with Proust. Many of these Proustian points of contact have already been noted by Adam Watt, whose analysis of Barthes's Journal concludes with the assertion that 'a close reading of the Journal de deuil reveals a persistent presence of the author of $A$ la recherche du temps perdu even on those pages where he is not explicitly evoked'. viii I wish to extend this observation to a consideration of the enigmatic formal structure of Barthes's Journal de deuil, under the aegis of Proustian intermittence. To this end I will first review the term's Proustian history, before demonstrating its adoption by Barthes and proposing intermittence as an interpretive tool for understanding Barthes's Journal in thematic and formal terms. Finally, intermittence in Proust and Barthes will be interrogated etymologically as a 'sending between' which opens out onto more general questions regarding the relationship between mourning and writing. Ultimately, my interest lies, like that of Steven Ungar, not only in 'Barthes read via Proust' or 'Proust read within Barthes', but especially in 'an ongoing movement between the two', which I find mirrored in the very concept of intermittence. ${ }^{\text {ix }}$ 


\section{Proustian Intermittence}

As is well known, Proust planned at an early stage in the genesis of his magnum opus to call the whole work Les Intermittences du Cœur, a title which, in itself, Diana Knight has described as 'wonderfully Barthesian'. ${ }^{\mathrm{x}}$ He changed his mind, however, after the publication in 1912 of a novel by Binet-Valmer under a title which he felt to be uncomfortably similar: Le Cour en désordre. ${ }^{\mathrm{xi}}$ The titular Intermittences of the Heart was, as a consequence, relegated to the title of a sub-section of what was eventually to be the fourth volume of Proust's work, Sodome et Gomorrhe. There, though comparatively hidden away, the concept of intermittence was to become a favourite and staple passage of the Recherche. Proust himself elevated intermittence to one of the fundamental psychological 'laws' of his novel, ${ }^{\text {xii }}$ and readers were not slow to appreciate the episode designated by this erstwhile general title, with Samuel Beckett famously applauding it as 'perhaps the greatest passage that Proust ever wrote' xiii The passage narrates the anachronism of mourning, which the protagonist only experiences suddenly and genuinely a year after his grandmother’s death:

A convulsion [Bouleversement] of my entire being. On the very first night, as I was suffering from an attack of cardiac fatigue [une crise de fatigue cardiaque], trying to overcome the pain, I bent down slowly and cautiously to remove my boots. But hardly had I touched the first button of my bottine, before my chest swelled, filled with an unknown, divine presence, I was shaken by sobs, tears streamed from my eyes. The person who had come to my assistance, who was rescuing me from my aridity of soul, was the one who, several years before, at an identical moment of 
distress and loneliness, a moment when I had no longer had anything of myself, had entered, and who had restored me to myself, for it was both me and more than me (the container which is more than the content, and had brought it to me). I had just glimpsed, in my memory, bent over my fatigue, the tender, concerned, disappointed face of my grandmother, such as she had been on that first evening of our arrival; the face of my grandmother, not that of the one whom I had been surprised and selfreproachful at having missed so little, who had nothing of her but her name, but of my true grandmother [ma grand-mère véritable], the living reality of whom, for the first time since the Champs-Elysées, where she had suffered her stroke, I had rediscovered in a complete and involuntary memory [un souvenir involontaire et complet]. This reality does not exist for us until such time as it has been recreated in our minds (otherwise the men who have been involved in some titanic battle would all be great epic poets); thus, in a wild desire to hurl myself into her arms, it was only at this instant — more than a year after her funeral, on account of the anachronism which so often prevents the calendar of facts from coinciding with that of our feelings — that I had just learned she was dead. ${ }^{\text {xiv }}$

Critics have rightly tended to consider this law of emotional intermittence as the darker, melancholic side of the more typically joyous experience of Proustian involuntary memory. ${ }^{\mathrm{xv}}$ The passage is also fundamental to analyses of the workings of Proustian mourning as nonlinear, unpredictable and thus non-Freudian (if we base our understanding of Freud on his early essay 'Mourning and Melancholia'). ${ }^{\text {xvi }}$ In short, 'The Intermittences of the Heart' demonstrate — in the words of L. Scott Lerner — 'that our definitions of "successful" and “normal” mourning are too rigid’ and that 'Perhaps even “normal” mourning can remain permanently incomplete. Not continuously, but intermittently. ${ }^{\text {xvii }}$ 
For my part, I would like to emphasize the interaction in this passage between physical and mental suffering; the protagonist is already suffering from 'an attack of cardiac fatigue' as he bends over and experiences the emotional heartbreak of 'The Intermittences of the Heart'. This continuity between bodily and emotional suffering not only relies on the obvious multivalence of the word 'heart' (traditionally both a beating organ and the seat of the emotions), but is also, as is less obvious, inherent in the concept of 'intermittence', a term which Proust borrowed and adapted from philosophical, scientific and medical discourse. ${ }^{\text {xviii }}$ Anne Henry has traced the term back to the start of the nineteenth century and to Xavier Bichat's Recherches physiologiques sur la vie et la mort (1800), and notes the importance, for the term's wider promulgation, of Arthur Schopenhauer's subsequent approval of Bichat's thesis. ${ }^{\text {xix }}$ According to Bichat, in humans there are two different levels of life at work: continuous ‘vie organique’ (organic life), responsible for such processes as digestion, circulation and respiration, as well as the emotions; discontinuous 'vie animale' (animal life), which involves movement, understanding and intelligence, all of which are liable to interruption or intermittence, as a result of tiredness, distraction, sleep or illness. ${ }^{\mathrm{xx}}$ At its origins, then, the term is linked to the body and to consciousness, and it was its associations with the latter which enabled its migration, in the course of the nineteenth century, from the domain of medicine to that of philosophy. In philosophical terms (those of Schopenhauer, but also of his French commentator, Théodule Ribot), intermittence was used to prove the bipartite nature of the self and to demonstrate the fragility and instability of consciousness and intelligence (Bichat's 'animal life') in contrast to the permanence of a simpler form of existence, which Bichat had called 'organic life’ and which Schopenhauer reformulated as will (in French, 'volonté'). ${ }^{\mathrm{xxi}}$

The philosophical meaning of intermittence would be attractive to Proust, whose own thought relied on a similar dualism, most famously, between voluntary and involuntary 
memory as between a social, superficial self and an authentic, hidden self, and who also shared Schopenhauer's devaluation of intelligence. ${ }^{\text {xxii }}$ Further, for Proust the transition from sleep to wakefulness evidently held at least as much fascination as it had for Bichat in terms of its implications for theories of consciousness and subjectivity. Yet Proust did not import the term wholesale from such sources, but rather transformed it by placing it at the heart of his own theory of the anachronism of emotions and the unpredictability of true, living memory (as demonstrated in the lengthy passage from Sodome et Gomorrhe cited above). Proustian intermittence thereby stands in direct contrast to that of Bichat and Schopenhauer, since while the latter pair connect intermittence to 'animal life' and to intelligence, Proust instead sees intermittence as embedded in the body and the emotions. For Bichat, this 'organic life' is continuous; for Proust, it is richly intermittent.

Proust's theory of intermittence thus subverts its purported origins, and indeed proves to owe more to a broader, less technical nineteenth-century usage, according to which intermittence is typically pathological and relates to the pulse, to circulation and the heart, to fever, to respiration and the lungs, and to associated illnesses. ${ }^{\text {xxiii }}$ Though Proust elaborated his own distinctive theory of intermittence, he never lost sight of such residual medical associations; the corporeal connotations of intermittence, like those of the heart with which it is paired, remain notably explicit and operative in Proust, alongside his idiosyncratic reimagining of the concept in affective terms. In the very letter in which he proposes Les Intermittences $d u$ Cœur as a potential title for the whole work, Proust clarifies that the term properly refers to 'une maladie du corps' (a bodily illness). ${ }^{\text {xxiv }}$ Within the Recherche, moreover, the medical origin of the word is acknowledged before its appropriation for the language of grief, significantly in the description of the grandmother's difficulties in breathing leading up to her death: 
At times it seemed as if it was all over: her breath stopped, either because of one of those shifts of octave that occur in the respiration of a sleeper or because of some natural interruption [intermittence], an effect of anaesthesia, developing asphyxia, a failure of the heart $[$ du cour $] .{ }^{\mathrm{xxv}}$

In this shared vocabulary between the two scenes, the death of the grandmother and the protagonist's mourning become intimate, interrelational, specular narrative moments, as the term 'intermittence', along with its paired term 'the heart', shifts in import between physical and emotional connotations. From this perspective, mourning is deeply empathetic, allowing the protagonist to participate, belatedly, in his grandmother's suffering.

The link between breathing and intermittence in the narrative of the grandmother's death leads to wider implications of intermittence on linguistic style and textual composition, especially if we follow Walter Benjamin's bold argument concerning the influence on his writing of the asthmatic Proust's own experience of breathing difficulties: 'That asthma became part of his art — if indeed his art did not create it. Proust's syntax rhythmically and step by step reproduces his fear of suffering. ${ }^{\text {xxvi }}$ From this perspective, the connection postulated by Ingrid Wassenaar between intermittence and language (including mise-enpage) is particularly astute:

Intermittence, astonishingly, emphasizes mental disconnection, sporadic blanks in a morse code, rather than being a representation of Time as agent of its own smoothly joined-up looping and spiralling effects on human activity. Intermittence is as much a theory of blank spaces on a page, as it is of mental systems. It is about mistimed interventions into the narration of suffering, and the deficient gobbets and gaps of speech by which suffering signifies in language. ${ }^{\text {xxvii }}$ 
This reading of Proustian intermittence as extending from a physical condition and an emotional state to a potential meta-narrative practice with identifiable stylistic and formal features underpins my interpretation of Barthesian intermittence in the Journal de deuil.

\section{Barthesian Intermittence}

Despite the many references to Proust in Barthes’s Journal charted by Watt, Watt also records that 'not once in the Journal de deuil does he make mention of "les intermittences du cœur”, xxviii This absence is all the more surprising when we consider that the passage is referenced explicitly by direct quotation in relation to Barthes's mourning for his mother in La Chambre claire:

For once, photography gave me a sentiment as certain as remembrance [le souvenir], just as Proust experienced it one day when, leaning over to take off his boots, there suddenly came to him his grandmother's true face [le visage de sa grand-mère véritable], 'whose living reality I was experiencing for the first time, in an involuntary and complete memory' ${ }^{x x i x}$

Instead, for an explicit borrowing of the Proustian word 'intermittence' in Barthes's æuuvre, we must turn to Le Plaisir du texte, where intermittence is argued to have seductive properties: 
It is intermittence, as psychoanalysis has so rightly stated, which is erotic: the intermittence of skin flashing between two articles of clothing (trousers and sweater), between two edges (the open-necked shirt, the glove and the sleeve); it is this flash itself which seduces, or rather: the staging of an appearance-as-disappearance [la mise en scène d'une apparition-disparition]. ${ }^{\mathrm{xxx}}$

This passage is a useful gloss on the workings of Proustian intermittence, since 'The Intermittences of the Heart' is legible as a similarly seductive, though likely more elegiac than erotic, 'staging of an appearance-as-disappearance'. For only in the apparition of the grandmother via involuntary memory does the protagonist learn of her disappearance: 'it was only at this instant (...) that I had just learned she was dead'. ${ }^{x x x i}$

Turning to the Journal, while Proust's intermittences may not be invoked in these notes explicitly, Barthes does, nonetheless, cite a specific phrase from shortly after this same episode, namely Proust’s protagonist’s mother’s experience of “'that incomprehensible contradiction of memory and nothingness"' $(M D, 160)$ faced with her mother's death. Variants on this same phrase are also used by Proust to define the mournful intermittence experienced by the protagonist. ${ }^{\text {xxii }}$ Moreover, Barthes's description of himself in the Journal as 'bouleversé' (overwhelmed) by a photograph of his mother no doubt points to the experience of 'Bouleversement' with which the narrative of Proustian intermittence begins, that is, the stark and fragmentary opening phrase ‘Bouleversement de toute ma personne’ (A convulsion of my entire being). ${ }^{\text {xxxiii }}$ Watt comments that this last phrase is 'so brief and telegraphic that it might seem more suited to the Journal de deuil than to the Recherche'.xxxiv Yet in general, Proust's lengthy sentences and paragraphs, stretching across seven not insubstantial volumes, are entirely unlike the fragmentary form and elliptical, sparse structure 
of Barthes’s Journal, especially compared to the dense black blocks of Proust's text as it appears in the Pléiade edition. ${ }^{\mathrm{xxx}}$

Ultimately, the Journal de deuil is manifestly more intermittent than Proust's novel, at least in formal terms. This formal intermittence may be partly a result of the diary form in general (since 'the diarist practice is by definition intermittent', according to Gérard Genette), as well as of Barthes's own ambivalence towards this genre; as he explains in 'Deliberation', 'I’ve never kept a journal — or, rather, I’ve never known if I should keep one. Sometimes I begin, and then, right away, I leave off — and yet, later on, I begin again. The impulse is faint, intermittent, without seriousness'. ${ }^{\text {xxxvi }}$ This intermittence is also, however, a formal replication and performance of the Journal's narrative of intermittent mourning. In the Journal, Barthes insists on the unpredictable, disordered, non-linear nature of his experience of mourning: 'my distress is chaotic, erratic' $(M D, 71)$. In addition to this pair of adjectives, Barthes also defines his grief as 'discontinuous' and 'immutable and sporadic' $(M D, 67,95)$. These adjectives stand as synonyms for the unuttered Proustian term, 'intermittent', and aptly characterize the Journal not only in terms of content but also in terms of form. Intermittence, though not named explicitly, is writ large formally as — to return to Wassenaar's formulation, which strikes me as even truer of Barthes’s Journal than Proust's Recherche 'a theory of blank spaces on a page'. xxxvii

In response to this formal intermittence, I would like to make two suggestions towards a hypothetical new edition of the Journal de deuil. The first is that the text be published as a box or folder of unbound sheets in order better to replicate both its original state and the disorder and discontinuity of Barthes’s grief. Although it may well be sensible and convenient, given the conventions of the diary form, to order the notes (the vast majority of which are helpfully dated) chronologically, such an order implies and to a certain extent creates a linearity and a teleology to which Barthes is strongly resistant in his description of 
his experience of the erractic nature of grief. An unbound edition would allow the reader to seek out and build new, non-chronological patterns in the text, which would remain necessarily unstable, impermanent and 'fluid' (another key, ideal attribute of mourning, according to the Journal: see $M D, 142)$. This rejection of chronology would also reflect the Proustian law of mournful intermittence, which confirms and embodies - to return to the passage from Sodome et Gomorrhe — 'the anachronism which so often prevents the calendar of facts from coinciding with that of our feelings' ${ }^{\text {xxxviii }}$

Closely linked to the greater instability of an unbound, unchronological text is my second suggestion, that these loose sheets be unnumbered, inspired by the example of Michel Deguy's A ce qui n'en finit pas: thrène, a series of reflections in note form written in the months following the death of the author's wife (17 January 1994) and published, though bound, without page numbers and undated. ${ }^{\text {xxxix }}$ As Deguy explains, 'The book will be unpaginated — because every page, or almost, might be the first, or the nth page. There is no ordinal series. Each page is a new beginning; each page is an ending' ${ }^{\mathrm{xl}}$ By eschewing pagination, Deguy's text is also resistant to habitual critical usage, in particular the dissection and repackaging of works into bite-sized chunks through excerption and quotation. Such a shock to conventional scholarly referencing systems would, in the case of the Journal de deuil, be a salutary reminder of the care and even trepidation with which we ought to approach this text, the publication of which was out of the hands and control of its author.

This brief thought experiment of an imaginary, Deguy-inspired, less user-friendly edition raises more wide-ranging questions, which involve not only editors, whether real or imagined, but all readers of Barthes's Journal. Put simply, how do we or how should we read this difficult to classify, voluntarily incomplete text? How does one read such a fragmentary work? At what speed? In what order, from front-to-back, or at random as the book falls open in our hands? No prescriptive answers to these questions are possible, but I do think it is 
worth reflecting further on the motives behind both the publication and the reading of Barthes’s Journal, and especially on the kind of 'lecteur intermittent' (intermittent reader) which this text seems to demand. ${ }^{\text {xli }}$

Here are Compagnon's gentle, hesitant thoughts on the subject:

Was it justifiable to publish this bundle of slips of paper, deeply private notes, written for himself after the death of his mother in October 1977 and not intended for others, traces of suffering, snippets of emotion leading gradually towards Camera Lucida, the monument raised in memory of his mother? I do not know, but I read these pages with considerable discomfort. ${ }^{\text {xlii }}$

Compagnon's situation might be unique as a friend of Barthes, ${ }^{\text {xliii }}$ yet he also reacted in a similar manner to the task of preparing Sodome et Gomorrhe for publication, describing 'The Intermittences of the Heart', like Beckett before him, as:

Perhaps the most intense and moving moment in the Recherche - in any case the one on which, transcribing drafts, collating variants, establishing the text, writing the notes for the Pléiade edition, I have never been able to work properly because the emotion which always choked me up [qui me serrait à chaque fois la gorge] was overpowering, reminding me as it no doubt did of the death of my own mother. ${ }^{\text {xliv }}$

In his empathetic reaction to both the Journal and Sodome et Gomorrhe, Compagnon stands as an exemplary figure for the reader's likely identification with and participation in the encountered narrative of mourning, in an extension of Barthes's own identification with Proust. ${ }^{x l v}$ For Barthes, moreover, literature might well be defined by this type of empathetic, 
visceral engagement. As he declares in the Journal, 'This is what literature is: that I cannot read without pain, without choking on truth [sans suffocation de vérité], everything Proust writes in his letters about sickness, courage, the death of his mother, his suffering, etc. xlvi With this note we return to the medical definition of intermittence as a difficulty in breathing, which is once more transposed into the experience of both grief and literature. Thus, while Barthes's Journal is more intermittent than Proust's Recherche in formal terms, both texts contribute more equally to the important thematic connection between breathing, suffering, mourning and writing, encapsulated in the concept of intermittence.

For Proust and Barthes, writing bears the marks of a painful, suffocating, erratic intermittence. For Proust's protagonist, intermittence-as-suffocation is, as noted above, part of a specular, empathetic participation in the grandmother's last agony. Similarly, Barthes remembers, in the Journal, his mother's 'souffle de l'agonie’ (dying breath) ( $J D, 50 ; M D$, 40), which is as if extended and replicated in the first illness he experiences after her death, bronchitis (MD, 97), as well as, more broadly, in his account of bereavement as 'a sort of black wing' which 'chokes my breathing' $(M D, 180)$, a rare moment of metaphor in the text. In this way, intermittence-as-suffocation becomes, for Barthes, a mode of mourning that, as in the 'Intermittences of the Heart', unites the deceased and the bereaved, combining the bodily and the medical with what is mournful and emotional.

The same also has, in the Journal, important implications for both reading and writing; suffocating intermittence is a physical ailment and a counterpart to mourning which assumes a literary function and form. It is a response to reading, and to reading Proust in particular ( $M D, 177$, cited above), which also fuels Barthes's own writing: 'that writing in which I put my very breath, where I caught my breath from suffering' $(M D, 121)$. Writing is where Barthes has some respite — a breather — from his mourning (in the original French, 'le reprendre souffle de mon chagrin’, JD, 132), but also where this mournful, broken 
breathing is most audible, where it is renewed and taken up again (in a different sense of reprendre), in the necessarily fragmented form of short, breathless, intermittent phrases. Here, finally, intermittence-as-suffocation unites not only deceased and mourner, but also mourner and reader, as the example of Compagnon has already attested. Following in the footsteps of Barthes reading Proust and Compagnon reading Proust and Barthes, we cannot but read the Journal de deuil as it was written, that is, intermittently, however difficult, troubling or choking that reading experience may be in practice.

Inter-mittere

In the final part of this essay, I want to bring a further connotation of intermittence to the fore: its etymological meaning of 'to send between', from the Latin inter-mittere. ${ }^{\text {xlvii }}$ This etymological implication might at first glance seem distant from other meanings of the word, in particular those relating to interruption, discontinuity and asphyxia discussed above. Yet this act of 'sending between' is, when interpreted as a figure for writing, strikingly predicated upon a similar possibility of failure and disruption in communication between writer and desired reader. Intermittence as in-betweenness is present in Barthes's discussion of 'the intermittence of skin flashing between two articles of clothing' in Le Plaisir du texte, and the already highlighted phrase with which this definition concludes — intermittence as 'la mise en scène d'une apparition-disparition' (the staging of an appearance-as-disappearance) — suits well both writing and reading as the staging (from mise-en-scène to mise-en-page) of a transient, fleeting encounter. ${ }^{\text {xlviii }}$ 
Intermittence as a potential failure in communication is nowhere clearer than in the narrative of a dream that Proust's protagonist has of his dead grandmother shortly after the episode of 'The Intermittences of the Heart':

'She must think I’ve forgotten her since she died, how alone and abandoned she must feel! Oh! I must run and see her, this very minute, I can’t wait for my father to come, but where is it? How can I have forgotten the address? If only she still recognizes me! How can I have forgotten her all these months?' It’s dark, I shan’t find her, the wind is stopping me advancing; but here is my father walking in front of me; I cry out to him: 'Where’s grandmother? Tell me the address. Is she all right? Is it quite certain she’s got all she needs? - No, no, my father says to me, you can rest assured. Her nurse is an orderly person. We send a very small sum from time to time so they can buy her the little she has need of. She sometimes asks what's become of you. She's even been told you were going to write a book. She seemed pleased. She wiped away a tear.' (Sodom and Gomorrah, 163)

This passage raises fascinating questions concerning the relationship between writing and mourning. The protagonist's father (or rather, his dream avatar) suggests that the protagonist's transformation into an author would be a source of comfort to the dead but somehow still living grandmother: as he reports, 'She seemed pleased. She wiped away a tear.' However, the detail that the protagonist has lost his grandmother's address is extremely telling, for not only can the protagonist not find or visit his grandmother, but nor can he write to her. In this respect, the fact that the protagonist may write a book cannot be truly meaningful or pleasing to his grandmother, because she will never be able to receive or read such a work. Here we have in miniature an illustration of the sad truth that in mourning we 
can only ever write about and not to the mourned beloved, or rather, that we can write to them, but this writing will never reach them and we will receive no reply, save the empty, mechanical, official and impersonal response: 'return to sender'.

Barthes’s Journal de deuil expresses a similar concern as to whom writing about mourning is directed. Barthes worries that this type of project is too self-absorbed, risking as it does being not only for but also only about oneself: 'Suffering [again, the Proustian term chagrin] is a form of egoism. | I speak only of myself. I cannot speak of her, say what she was' (MD, 195; $J D, 208)$. In contrast, what moves Barthes on rereading his notes are the parts which do seem an adequate record of some aspect of his mother: 'Tears each time there was any question of her — of her person — not of me' $(M D, 151)$. Barthes's ability to connect to his mother through his writing is an unstable, intermittent, interrupted process. Yet this intermittence has two principal virtues: firstly, openness to the unpredictable advent of the deceased in one’s heart, memory and dreams; secondly, respect for the other as desirable by reason of being unreachable and opaque. The loss of address, illustrated in Proust's protagonist's dream, does not absolve the mourner from attempting, however, futilely, to reach out to the deceased through writing.

These qualities of openness and respect, achieved through the Journal's intermittent, fragmented form, might seem more important for Barthes's autobiographical project than for Proust's novel, which in its literariness is inevitably at a certain, difficult-to-pinpoint distance from Proust's own mourning for his mother (even if Barthes tends to read the Recherche more or less directly as a response and a witness to this experience). ${ }^{x l i x}$ In other words, Proust has greater freedom as author of a fictionalized universe than does Barthes, who wants his notes to contain something of his own mother more directly, though couched within a project that remains eminently literary in its engagement with bookish precursors (most notably, Proust). ${ }^{1}$ 
Nonetheless, the concept of respectful mourning, so crucial for Barthes’s Journal, is also borrowed from, or rather consonant with, Proust's 'Intermittences of the Heart', in particular the narrator's observation that 'I was anxious not to suffer only, but to respect the originality of my suffering' (Sodom and Gomorrah, 161). Barthes adopts these lines as his own in La Chambre claire:

I might say, like the Proustian Narrator at his grandmother's death: 'I did not insist only upon suffering, but upon respecting the originality of my suffering'; for this originality was the reflection of what was absolutely irreducible in her, and thereby lost forever. (Camera Lucida, 75)

This quest for originality is a desire to capture in writing something essential, unique and therefore, alas, potentially unwriteable. The language of mourning as intermittence ceaselessly navigates the stormy waters not only between self-pity and the unreachable beloved, but also between the threat of cliché and the demands of impossible fidelity to the deceased. Barthes laments in the Journal that 'Death, Suffering are nothing but: banal' (222), and strives throughout against the risk of linguistic and formal banality. In this respect, intermittence as an unreliable, disrupted, frustrated attempt at communication implicates all readers of the mournful text, and not simply the beloved whose address is unknown.

It is for such reasons that Barthes's Journal constitutes a rejection of literariness (in the sense of codes, conventionality and generic expectations), even though Barthes knows, at heart, that it is only through literature that language can be saved from such pitfalls: 'I don't want to talk about it, for fear of making literature out of it — or without being sure of not doing so — although as a matter of fact literature originates within these truths' $(M D, 23)$. In this endeavour, intermittence is once more essential as a flexible, unpredictable and 
unashamedly literary movement between the two equally unacceptable alternatives of cliché and illegibility.

Conclusion: In Praise of Intermittence

Proust's 'Intermittences of the Heart' has long been recognized and admired as a pivotal, fundamental passage within the Recherche as a whole, yet this multifaceted analysis of the concept of intermittence, in particular by way of comparison with its adoption by Barthes, enables the full implications of the term and its relevance to the experience of mourning to be newly appreciated. As a result of this comparative analysis, the concept of intermittence has been found to mobilize a wide range of connotations, from its origins in medical and philosophical discourse and its literary reappropriation as an emotional force with formal consequences, to its etymological meaning of 'sending between' (with the attendant risk of a communication breakdown). Throughout, intermittence has emerged as constitutive of both mourning and writing about mourning, enabling not only a new appreciation of Proustian intermittence, but also a better understanding of Barthes's Journal de deuil, in particular its fragmented form. The Journal replicates formally its narrative of intermittent mourning more faithfully, or at least more literally, and certainly more radically than its literary precursor. Yet both works share a commitment to intermittence as an emotional truth that helps to navigate between the melancholic strictures of mourner and mourned, life and death, survival and oblivion, narrative and silence, and author and reader. Intermittence, to conclude, is vital to an understanding of mourning as an organic, chaotic, non-teleological force which, in exerting pressure on language, produces new ways of writing about and through grief. 
${ }^{\mathrm{i}}$ I cite throughout from the English translation In Search of Lost Time, edited by Christopher Prendergast, 6 vols (London: Allen Lane, 2002), in particular the following volumes: In the Shadow of Young Girls in Flower, translated by James Grieve; The Guermantes Way, translated by Mark Treharne; Sodom and Gomorrah, translated by John Sturrock. Where necessary, references to the original are to A la recherche du temps perdu, edited by Jean-Yves Tadié, 4 vols (Paris: Gallimard, 1987-9), hereafter abbreviated as ALR. For the Journal, see Roland Barthes, Journal de deuil: 26 octobre 1977 - 15 septembre 1979, edited by Nathalie Léger (Paris: Seuil/Imec, 2009) and Mourning Diary: October 26, 1977 - September 15, 1979, edited by Nathalie Léger, translated by Richard Howard (New York: Hill and Wang, 2010), though I cite from the later edition Mourning Diary (London: Notting Hill Editions, 2011). Subsequently these two texts are abbreviated as JD and MD respectively.

ii In contrast, for a different reading of intermittence in modern French theory, see Marta Segarra, 'Cixous, Derrida and Psychoanalysis: The Principle of Intermittence, or Dwelling on the Angle’, Paragraph 36:2 (2013), $240-54$.

iii Most typically, Barthes's Mourning Diary has been situated alongside other mournful works of the 'late Barthes', in particular La Chambre claire (Camera Lucida): see Neil Badmington, 'Punctum Saliens: Barthes, Mourning, Film, Photography’, Paragraph 35:3 (2012), 303-19, and Éric Marty, Roland Barthes, la littérature et le droit à la mort (Paris: Seuil, 2010). Most recently, the text’s religious language is analysed in Emma Mason, 'Punctive Grace: Reading Religion in Barthes’ Mourning Diary', Textual Practice 30:2 (2016), 327-43, while Wernmei Yong Ade reads the Journal in relation to the myth of Orpheus and to Barthes's Fragments d'un discours amoureux (A Lover's Discourse: Fragments) in 'Mourning Diary: Love’s Work', Textual Practice 30:2 (2016), 345-62. See also Diana Knight, 'Dernière musique: sur l'air de Roland Barthes dans Journal de Deuil' in Barthes et la musique, edited by Claude Coste, Sylvie Douche and Éric Marty (Rennes: Presses Universitaires de Rennes, forthcoming).

iv See: Antoine Compagnon, 'Proust et moi' in Autobiography, Historiography, Rhetoric: A Festschrift in Honor of Frank Paul Bowman, edited by Mary Donaldson-Evans, Lucienne Frappier-Mazur and Gerald Prince (Amsterdam: Rodopi, 1994), 59-73; Diana Knight, 'Roland Barthes, or The Woman Without a Shadow’ and Beryl Schlossman, 'The Descent of Orpheus: On Reading Barthes and Proust' in Writing the Image After Roland Barthes, edited by 
Jean-Michel Rabaté (Philadelphia: University of Pennsylvania Press, 1997), 132-43 and 144-59 respectively; Diana Knight, Barthes and Utopia: Space, Travel, Writing (Oxford: Clarendon Press, 1997), especially 244-69; Malcolm Bowie, 'Barthes on Proust’ and Lawrence D. Kritzman, 'Barthes’s Way: Un amour de Proust', The Yale Journal of Criticism 14:2 (2001), 513-18 and 535-43 respectively; Jean-François Chevrier, 'Proust par Roland Barthes’ in Prétexte: Roland Barthes: colloque de Cerisy, edited by Antoine Compagnon (Paris: Christian Bourgois, 2003), 413-38; Kathrin Yacavone, 'The “Scattered” Proust: On Barthes’s Reading of the Recherche' in When Familiar Meanings Dissolve: Essays in French Studies in Memory of Malcolm Bowie, edited by Gill Rye and Naomi Segal (Oxford: Peter Lang, 2011), 219-31; Thomas Baldwin, ‘On Barthes on Proust', Forum for Modern Language Studies 48:3 (2012), 274-87; Katja Haustein, Regarding Lost Time: Photography, Identity, and Affect in Proust, Benjamin, and Barthes (Oxford: Legenda, 2012).

v Yacavone describes the presence of Proust in Barthes as 'intermittent' in 'The "Scattered” Proust', 220, while Compagnon speaks of reading Proust as 'aléatoire ou intermittente' (aleatory or intermittent) in 'Proust et moi', 70.

vi The Pleasure of the Text, translated by Richard Miller (London: Jonathan Cape, 1976), 36.

vii I borrow this phrase from Darian Leader, The New Black: Mourning, Melancholia and Depression (London: Penguin, 2008), 78 (emphasis in the original).

viii Adam Watt, 'Reading Proust in Barthes’s Journal de deuil', Nottingham French Studies 53:1 (2014), 102-12 (112).

ix Steven Ungar, 'Circular Memories: Via Proust' in Roland Barthes: The Professor of Desire (Lincoln, NE: University of Nebraska Press, 1983), 135-51 (136).

x See Proust, Correspondance, edited by Philip Kolb, 21 vols (Paris: Plon, 1970-93), XI, 257, and Knight, Barthes and Utopia, 261.

xi See Proust, Correspondance, XII, 176-7, and also Jean Yves-Tadié, Marcel Proust: biographie (Paris: Gallimard, 1996), 701-2.

${ }^{\text {xii }}$ For instance, in the phrase 'one of the laws of human make-up [cette âme humaine] being intermittence, which is further affected by the unpredictable recurrence of different memories' (In the Shadow of Young Girls in Flower, 167; ALR I, 581).

xiii Beckett, Proust (London: Calder, 1965), 39.

${ }^{\text {xiv }}$ Proust, Sodom and Gomorrah, 158; ALR III, 152-3. 
${ }^{\text {xv }}$ See, for instance, Antoine Compagnon, Proust entre deux siècles (Paris: Seuil, 1989), 144, and Inge Crosman Wimmers, Proust and Emotion: The Importance of Affect in 'A la recherche du temps perdu' (Toronto: University of Toronto Press, 2003), 60.

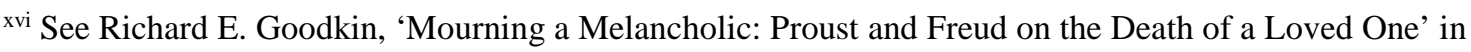
Around Proust (Princeton: Princeton University Press, 1991), 127-45, Alessia Ricciardi, The Ends of Mourning: Psychoanalysis, Literature, Film (Stanford: Stanford University Press, 2003) and the work of Anna Magdalena Elsner on mourning and Proust, in her doctoral thesis 'Mourning and Creativity in A la recherche du temps perdu' (University of Cambridge, 2010), and Mourning and Creativity in Proust: Psychoanalysis and the Ethics of Creation (Basingstoke: Palgrave Macmillan, forthcoming). Both Elsner and Goodkin warn against reducing Freudian mourning to his early essay. For a discussion of Barthes as providing an alternative to the Freudian binary of mourning and melancholia, see Kathleen Woodward, 'Freud and Barthes: Theorizing Mourning, Sustaining Grief', Discourse: Journal for Theoretical Studies in Media and Culture 13:1 (Fall-Winter 1990-1), 93-110.

xvii L. Scott Lerner, 'Mourning and Subjectivity from Bersani to Proust, Klein, and Freud’, Diacritics 37:1 (Spring 2007), 41-53 (53, emphasis in the original).

xviii See the entry on 'intermittence' by Anne Henry in the Dictionnaire Marcel Proust, edited by Annick Bouillaguet and Brian G. Rogers (Paris: Honoré Champion, 2004), 514-15.

xix Anne Henry, La Tentation de Marcel Proust (Paris: Presses Universitaires de France, 2000), 88-9.

${ }^{\mathrm{xx}}$ See Xavier Bichat, Recherches physiologiques sur la vie et la mort (Paris: Chez Brosson, Gabon et Cie, 1800), especially $40-6$ on the intermittences of animal life. I am grateful to the librarians of Christ Church, Oxford, for allowing me to consult this volume.

xxi See Théodule Ribot, La Philosophie de Schopenhauer (Paris: Librairie Germer Baillière), 73-5, and, on Ribot, Edward Bizub, Proust et le moi divisé: la ‘Recherche’: creuset de la psychologie expérimentale (18741914) (Geneva: Droz, 2006), 51, and Henry, La Tentation, 88.

xxii As the famous, stark opening of Contre Sainte-Beuve declares: 'Chaque jour j’attache moins de prix à l'intelligence’ (Every day I attach less importance to intelligence). Proust, ‘[Projets de préface]' in Contre Sainte-Beuve précédé de Pastiches et mélanges et suivi de Essais et articles, edited by Pierre Clarac with Yves Sandre (Paris: Gallimard, 1971), 211-18 (211). 
xxiii See the entry for 'intermittence’ in Pierre Larousse, Grand dictionnaire universel du XIXe siècle, 17 vols in 34 (Geneva: Slatkine, 1982 [originally Paris: Administration du Grand dictionnaire universel, 1866-79]), IX(ii), 754.

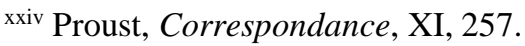

${ }^{x x v}$ Proust, The Guermantes Way, 342; ALR III, 639.

xxvi Walter Benjamin, ‘The Image of Proust’ in Illuminations, edited by Hannah Arendt, translated by Harry Zorn (London: Pimlico, 1999), 197-210 (209).

xxvii Ingrid Wassenaar, Proustian Passions: The Uses of Self-Justification for 'A la recherche du temps perdu' (Oxford: Oxford University Press, 2000), 124.

xxviii Watt, 'Reading Proust', 110.

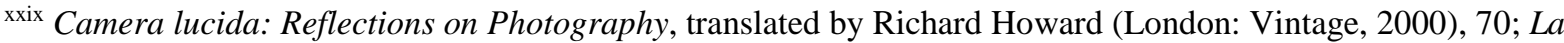
Chambre claire: note sur la photographie in Euvres complètes, edited by Éric Marty, new edition, 5 vols (Paris: Seuil, 2002), V, 785-892 (845). See Antoine Compagnon, 'Proust et moi’, 72, and Éric Marty, 'Marcel Proust dans « la chambre claire »', L’Esprit créateur 46 (2006), 125-33.

xxx The Pleasure of the Text, 10; Le Plaisir du texte in Euvres complètes, IV, 217-63 (223).

xxxi Sodom and Gomorrah, 158.

xxxii See, for instance, Sodom and Gomorrah, 161, for a similar assertion of 'this strange contradiction between survival and oblivion'.

xxxiii See $M D, 143$; JD, 155, and ALR III, 152; Sodom and Gomorrah, 158. This connection is also made by Watt, 'Reading Proust', 110-11, and the intertext is confirmed by the passage from Camera Lucida cited above. In the Journal, dreams, too, have a similar power of bouleversement $(M D, 107 ; J D, 118)$.

xxxiv Watt, 'Reading Proust', 111.

xxxv See, nonetheless, Malcolm Bowie, 'Postlude: Proust and the Art of Brevity’ in The Cambridge Companion to Proust (Cambridge: Cambridge University Press, 2001), 216-29.

xxxvi See Gérard Genette, 'The Diary, the Anti-Diary’ in Essays in Aesthetics, translated by Dorrit Cohn (Lincoln, NE: University of Nebraska Press, 2005), 116-24 (118), and Barthes, 'Deliberation' in The Rustle of Language, translated by Richard Howard (Berkeley and Los Angeles: University of California Press, 1989), 359-73 (359), as well as Éric Marty, Roland Barthes, la littérature et le droit à la mort, and more generally the essays in Deliberations: The Journals of Roland Barthes, edited by Neil Badmington, Textual Practice 30:2 (2016). 
xxxvii Wassenaar, Proustian Passions, 124.

xxxviii Proust, Sodom and Gomorrah, 158.

xxxix See Michel Deguy, A ce qui n’en finit pas: thrène (Paris: Seuil, 1995).

xl Translation my own. It is evidently not possible to provide a page reference.

xli I take the phrase 'lecteur intermittent’ from André du Bouchet, Matière de l'interlocuteur ([Montpellier]: Fata Morgana, 1992), 25, via Emma Wagstaff, Provisionality and the Poem: Transition in the Work of du Bouchet, Jaccottet and Noël (Amsterdam: Rodopi, 2006), 32.

xlii Antoine Compagnon, ‘Writing Mourning’, translated by Sam Ferguson, Textual Practice 30:2 (2016), 209_ 19 (210). For the original French text, see Compagnon, ‘Écrire le deuil’, Acta fabula 14:2 (February 2013), « Let’s Proust again! », http://www.fabula.org/acta/document7574.php, consulted 6 December 2015.

xliii For a memoir of this friendship, see Compagnon, L’Âge des lettres (Paris: Gallimard, 2015).

xliv See Compagnon, 'Proust et moi', 72. Translation my own.

${ }^{\mathrm{xlv}}$ At the start of his lecture 'Longtemps, je me suis couché de bonne heure...', Barthes explains 'I am not in the least comparing myself to this great writer [Proust] but, quite differently, identifying myself with him: an association of practice, not of value'. Cited from The Rustle of Language, translated by Richard Howard (Berkeley and Los Angeles: University of California Press, 1989), 277-90 (277, emphasis in the original). ${ }^{x l v i} M D, 177 ; J D, 189$. Here, as elsewhere in the Mourning Diary, the word 'suffering' translates Barthes's deliberate preference for the Proustian term 'chagrin' rather than 'deuil' to designate the experience of mourning. As Barthes remarks, 'Proust speaks of suffering [chagrin], not mourning [deuil] (a new, psychoanalytic word, one that distorts)' (MD, 156; JD, 168), a point also highlighted by Watt, 'Reading Proust', 105, and by Elsner, 'Mourning and Creativity', 7-8 and 29.

xlvii This etymology is given in the entry for 'intermittent' in Larousse, Grand dictionnaire universel du XIXe siècle, IX(ii), 754, and is confirmed by the entry in the OED for 'to intermit' (from the Latin 'intermittěre', formed from inter between + mittěre to send), http://www.oed.com/, consulted 6 December 2015. A love of etymologies is shared by both Proust and Barthes: see Compagnon, 'Brichot: étymologie et allégorie' in Proust entre deux siècles, 229-56, and Cécile Hanania, Roland Barthes et l'étymologie (Brussels: P.I.E. Peter Lang, 2010).

xlviii The Pleasure of the Text, 10 (my emphasis); Le Plaisir du texte, 223.

xlix See, besides the Journal, Barthes, 'Longtemps, je me suis couché de bonne heure...'. 
${ }^{1}$ Regarding the literariness of the Journal, Marty also persuasively argues for Mallarmé and St Augustine as sources of inspiration in Roland Barthes, la littérature et le droit à la mort, 28-30 and 35-7. 